\title{
CORPORATE SOCIAL RESPONSIBILITY REPORTING OF TWO NOTE-ISSUING BANKS IN HONG KONG
}

\author{
Dr Freda Hui ${ }^{1}$ \\ School of Accounting \& Finance, University of Wollongong \\ Graham Bowrey \\ School of Accounting \& Finance, University of Wollongong
}

\begin{abstract}
The environmental performance and management disclosure of organisations came under increased scrutiny over the past decade due to several factors, particularly the impact organisations have on the world's environment and the rapid change in the world's climate. These concerns prompted organisations, including financial institutions, to review the level of their environmental performance and management disclosures to demonstrate, amongst other objectives, their level of social responsibility. Due to the nature of their business, financial institutions are not generally seen to contribute directly to the degradation of the environment; however, they do provide the funds for many organisations' projects which directly affect the environment.
\end{abstract}

This paper reviews the environmental performance and management disclosure developments in China specifically by two note-issuing banks in Hong Kong: the Hongkong and Shanghai Banking Corporation (HSBC) and the Bank of China (Hong Kong) Limited (BOCHK) from 2003 to 2006. The review is conducted with reference to the Equator Principles, a voluntary environmental performance framework developed specifically for financial institutions. The paper also contributes to the literature on legitimation theory, using a social constructionalist perspective of legitimation.

Keywords: Environmental reporting, equator principles, legitimation, Hongkong and Shanghai Banking Corporation (HSBC), Bank of China

\footnotetext{
*The authors wish to acknowledge the advice and mentoring given by Professor Christine Cooper through the University of Wollongong School of Accounting and Finance Academic Mentoring Scheme. Thanks are also due to the Faculty of Commerce for funding the scheme.
}

\section{Introduction}

The state of the world's environment and the impact human beings have on the ecology of the world has led to increased public concern and scrutiny of the operations and performance of organisations. Organisations are now expected to demonstrate their awareness and addressing of the impact of their operations on the environment and society in general. Although private sector financial institutions, such as banks, do not significantly contribute directly to the degradation of the environment, they provide project funding for many organisations whose operations do. Coulson explains that "from an ethical perspective... a lender financing corporate activity should take some responsibility for the social and environmental impact of their transactions” (2007, p. 267). However, no mandatory environmental reporting disclosure requirements exist for private sector financial institutions in Hong Kong. Instead, Hong Kong banks voluntarily produce individual environmental performance and management reports. This paper reviews the environmental reporting practices in China of two note-issuing banks

\footnotetext{
${ }^{1}$ Corresponding author. Email fredah@uow.edu.au
} 
in Hong Kong: the Hongkong and Shanghai Banking Corporation (HSBC), which has adopted the Equator Principles, and Bank of China (Hong Kong) Limited (BOCHK), which has not, for the period 2003 to 2006. This paper also focus on the processes these two banks use to establish a relationship between their actions and their values through environmental performance reports.

The next section discusses the current state of environmental performance and management reporting with specific reference to the two Hong Kong banks. This is followed by a discussion of the Equator Principles and how legitimation theory may apply to environmental reporting. Finally, conclusions are drawn.

\section{Environmental Reporting}

Over the past two decades, an increasing number of organisations in both the public and private sectors have developed and produced reports on their environmental performance and management. This increase in environmental reporting has been linked to several drivers, such as greater societal concern with the impact of organisations operations on the environment (Ho et al., 1994) and increased expectations by society of organisational behaviour (Adams, 2004; Deegan, 2002; O’Donovan, 2002). Environmental reporting may also be due to organisations recognising environmental and social risks to, or opportunities for greater, profitability (Burritt and Welch, 1997, p. 542; Coulson, 2007, p. 266). Deegan suggests that environmental disclosure (adoption) decisions may be driven by the desire to survive (or be seen as legitimate), or by management's "view that the community has a right to know about the organisation’s actions” (Coulson, 2007, p. 144).

Most environmental reporting by organisations is voluntary and not required by regulation (Wilmshurst and Frost, 1999, p. 10), which affects the consistency and comparability of the various environmental reports. This has led to the suggestion that generally, only good news is reported (Deegan and Rankin, 1996; Burritt and Welsh, 1997), because organisations have no legal requirement to disclose. Where legislation on environmental reporting exists, it is generally based on breaches, rather than positive performance, which reflects the reporting practices of organisations. For the finance industry, Coulson describes how:

... as environmental legislation has increased bank lenders have developed riskassessment procedures to offset potential liability from environmental damage caused by their borrowers (2007, p. 267).

This suggests that the environmental disclosures by banks are focused on limiting exposures due to environmental impacts of projects that they have financed, rather than on the actual environmental impact of the project.

Several private sector organisations have voluntarily provided reports, of varying degrees detail, on their environmental performance and management. This voluntary reporting led to the development and implementation of several different types of reporting, such as triple-bottom-line reporting, ${ }^{2}$ which incorporates environmental, financial and social performance. However, even though the number of private sector organisations quite explicitly outlining their environmental successes in their annual report is growing, there is a notable absence of reporting of organisations' environmental failures.

\footnotetext{
${ }^{2}$ A triple-bottom-line report is defined as "a publicly released document that provides information about the social, environmental and economic performance of the reporting organisation”(Deegan, Cooper and Shelly 2005, p. 2).
} 
Hong Kong has no mandatory requirement for listed companies to disclose their environmental management and performance, and the enforcement of social and environmental legislation is negligible (Ng, 2000; Gao et al. 2005; Ho et al., 1994). However, since 1998, government departments, bureaux and government-owned organisations have been required to publish yearly environmental reports, disclosing their environmental performance (The Hong Kong Institute of Chartered Secretaries, 2006; Chiu et al., 2002). The introduction of mandatory environmental reporting in the public sector in Hong Kong is an attempt to encourage the private sector to adopt similar reporting practices; yet environmental reporting in the private section in Hong Kong is still at a nascent stage. This outcome reflects that Hong Kong companies have traditionally faced little external pressures for disclosing social and environmental information (Lynn, 1992; Ng, 2000; Gao et al., 2005).

So, why do an increasing number of organisations develop and produce voluntary environmental performance and management reports? Some commentators (Adams, 2004; Deegan, 2002; O’Donovan, 2002) suggest that organisations are motivated by an implied social contract between the organisation and members of society (stakeholders) to legitimise various activities of their respective organisations. Deegan (2002) explains that this motivation for voluntary environmental reporting contrasts to the perceived (accepted) reason for external reporting; that is, managers accept they are required, to give an account of (disclose) the organisation's total performance - financial as well as environmental (Adams 2004, p. 732). To be accountable, the environmental reports should be "transparent and represent a genuine attempt to provide an account which covers negative as well as positive aspects of all material impacts” (Adams 2004, p. 732). Deegan (2002) also suggests that several other possible motivations might explain why an organisation may decide to disclose their environmental performance and management, such as: to comply with legal requirements; economic rationality considerations; to comply with borrowing requirements; community expectations; to manage particular stakeholder groups; to comply with industry requirements or particular codes of conduct; to forestall efforts to introduce more onerous disclosure regulations; and to win particular reporting awards (Deegan 2002, pp. 290-291). For example, the $\mathrm{ACCA}^{3}$ recognises and awards organisations, irrespective of which sector they operate in, "for excellence in environmental, social and sustainability reporting" (ACCA, 2008a). The aim of the awards are "to give recognition to those organisations which report and disclose environmental, social or full sustainability information; encourage the uptake of environmental and sustainability reporting; and raise awareness of corporate transparency issues” [emphasis added] (ACCA, 2008b).

Due to the nature of voluntary reporting, organisations will not always disclose all relevant information from a stakeholder perspective. Besides the option for including or excluding negative information in environmental reports, there is also:

A lack of consensus on key issues such as the objectives of reporting, the qualitative characteristics the information should possess; the audience of the reports; the "best" presentation formats, and so forth (Deegan 2002, p. 286).

One possible motivation identified by Deegan why organisations decide to disclose environmental performance and management - to comply with industry requirements or particular codes of conduct (2002, p. 291) — addresses the issue of environmental report consistency. Gray and Bebbington identify "to legitimise current activity... to forestall legislation" (2001, p. 208) and to "forestall criticism” (2001, p. 234). However, it is not a

\footnotetext{
${ }^{3}$ ACCA (the Association of Chartered Certified Accountants) is a global body for professional accountants with over 320,000 members and students in 170 countries.
} 
simple task (Gray and Bebbington 2001, p. 209) to identify the specific reasons why some organisations provide voluntary environmental performance and management disclosures, and organisations are unlikely to admit that they disclose to forestall legislation. Some voluntary reports are included in an organisation's annual report, and some are stand-alone documents, sometimes labelled corporate sustainability responsibility (CSR) reports. The use of specific reports and reporting methods has also increased, such as triple-bottom-line reports, which incorporate the environmental, social and economic performance of the reporting organisation (Deegan, Cooper and Shelly, 2005, p. 2). However, as Gray and Bebbington explain, "it is rare to find consistent, systematic reporting of much that could be construed as other than public relations 'puff'” (2001, p. 239). The next section of this paper discusses the one group of voluntary reporting industry requirements, Equator Principles, which were developed and implemented by the international financial industry.

\section{Equator Principles}

In 2003 leading global lending institutions developed a set of principles, the Equator Principles, as a way to encourage private lenders to consider social and environmental issues when providing funding for infrastructure projects (Dillard et al., 2004, p. 508, Deegan, 2006, p. 275). The Equator Principles (refer to Appendix 1) are based on the International Finance Corporation's ${ }^{4}$ (IFC) minimum environmental and social policy framework for providing financial support to projects (Coulson, 2007, p. 270; Wright 2007, p. 2), and are voluntary guidelines with a primary focus on project financing issues in developing countries (Andrew, 2007, p. 41). The adoption of the Equator Principles by a financial institution implies that "a bank needs to justify why they are progressing a transaction [financing a project]" (Coulson, 2007, p. 274). Deegan also suggests that:

...having a code of environmental management could arguably be seen as a symbolic commitment to improved environmental performance by the industry body that developed the code, and by those companies who commit to it (Deegan, 2007, p. 141).

The Equator Principles were revised in 2006 by member organisations to address several concerns (limitations) of the earlier principles, such as reducing the threshold of projects when the principles are applicable. Andrew (2007) explains how the most significant change was the inclusion of Principle 10, which outlines that each funding organisation that adopts the Equator Principles is to "report publicly at least annually about its Equator Principles implementation processes and experience, taking into account appropriate confidentiality considerations" (http://www.equatorprinciples.com/documents/Equator_Principles). However, this is not seen as enough, as Coulson explains: "[there] are increased calls for... some formal association with an ombudsman and some means of auditing performance” (2007, p. 274).

Initially, only ten banks adopted the Equator Principles (Missbach, 2004, p. 78), but by the end of June 2008 approximately 60 private lending institutions had "signed on" to adopt the principles (www.equator-principles.com) - they had "promised that they will take some responsibility for the environment and social impact of the projects they finance" [emphasis added] (Missbach, 2004, p. 79).

On the surface this may be a positive development — financial institutions voluntarily agreeing to place a greater amount of emphasis on the environment and acknowledging the

\footnotetext{
${ }^{4}$ International Finance Corporation is the private sector lending arm of the World Bank Group (Wright, 2007, p. 2).), whose mission evolved from a facilitator of post-war reconstruction and development to its present-day mandate of worldwide poverty alleviation (World Bank, 2008).
} 
possible impact on the environment of the infrastructure projects for which they provide funding. However, underneath, several concerns are glossed over by the adoption of the Equator Principles. For example, Missbach (2004) explains that:

The principles apply only to a very small fraction of a bank's activities... they are weakened by not being applied to project finance deals where a bank may be a financial advisor, underwriter, arranger or lead manager (Missbach, 2004, p. 79).

Thus, when a bank promotes their adoption of the Equator Principles, they may perform several activities associated with funding an infrastructure project and yet not be required to abide by the Equator Principles. For example, they may perform a financial advisory role for an infrastructure project, rather than provide funding, and therefore are not required to approach this role under the guidance of the Equator Principles (Missbach, 2004). Also, "many transactions [project finance] are carried out as a syndication exercise" (Coulson, 2007, p. 270). Another concern is the lack of independent monitoring process, where projects funded by an Equator Principle Financial Institution can be assessed as completed as per the Equator Principles (Wright, 2007, p. 9). This concern is compounded by lack of overseeing body (Missbach 2004; Wright 2007), and all communication with stakeholders is through the Equator Principles website, which is "hosted by one of the adopting banks on a rotating basis" (Wright, 2007, p. 9). These point to potential conflicts of interest.

While one of the key aspects of the Equator Principles is their voluntary nature, surprisingly, a very explicit disclaimer appears at the end of the principles:

DISCLAIMER: The adopting EPFIs view these Principles as a financial industry benchmark for developing individual, internal social and environmental policies, procedures and practices. As with all internal policies, these Principles do not create any rights in, or liability to, any person, public or private. Institutions are adopting and implementing these Principles voluntarily and independently, without reliance on or recourse to IFC or the World Bank (www.equator-principles.com).

This raises the question why a private lending institution would adopt the Equator Principles if they are voluntary, not monitored and covered by a explicit disclaimer. Wright and Rwabizambuga (Wilmshurst and Frost, 1999; O’Donovan, 2002) suggest that all Equator Principle financial institutions will benefit from membership, irrespective of their actual practices, because no processes exist to "monitor the corporate practices of members" (p. 91). Gray and Bebbington also suggest that:

The environmental agenda is threatening significant change to the banks' modus operandi. Not only are there the direct and potential financial problems but the environment raises important ethical questions that financiers cannot dodge for much longer (1994, p. 186).

This is consistent with Deegan's question: ....are such [environmental disclosures] really reflective of an acceptance that an organisation has an accountability for its social and environmental performance, or are they merely a mechanism to support the existence of the organisation? (2007, p. 143).

In this situation the difficulty is to determine whether the drive for adoption is based on internal pressures from individuals who believe the institution should be environmentally accountable, while those responsible for the corporate governance of the institution see environmental disclosure as a process for the institution to gain legitimacy. Lohmann (2008) 
suggests that environmental accounting (adoption of the equator principles) due to political pressures is caused by the need to respond to market solutions by the perceived need (p. 31). From the banks' point of view, the problem of business risk exposure due to providing finance to organisations has three elements: (1) increased costs due to environmental problems created by the borrower, (2) bank may become responsible for the environmental liabilities attached to the property due to liquidation of the borrower, and (3) partial responsibility for clean-up costs associated with being a partnership with the borrower (Gray and Bebbington, 1994).

There are also benefits for organisations that adopt voluntary codes, such as the Equator Principles, because they will be seen as operating within best practices (Wright and Rwabizambuga, 2006, p. 95). The Equator Principles offer the financial sector an opportunity to jump on the bandwagon of environmental reporting in an explicit way which in turn increases the legitimacy of their institutions (Andrew, 2007, p. 44).

The following section discuses the theoretical framework of this paper: legitimation.

\section{Legitimation}

Legitimacy theory is the theoretical framework in vogue for several years that attempts to explain why organisations conduct certain activities such as implementing voluntary environmental reporting (Deegan, 2006, p. 275, Dillard et al., 2004, p. 508). Legitimacy theory asserts that organisations continually work to ensure that their activities are externally perceived as "legitimate" due to the notion that a social contract exists between society and the organisation (Deegan, 2006, p. 276; Deegan, 2007, p. 127). This is consistent with Deegan's explanation, that “organisations exist to the extent that the particular society considers that they are legitimate” (2007, p. 131). Guthrie and Parker (1989, p. 340) suggest that organisations disclose their environmental performance (at least the favourable component) so they may be perceived as reacting positively to the environment (p. 344), which is essential for influencing legitimacy (Deegan 2007, p. 139).

This paper reviews two banks' environmental reporting for the period 2003 to 2006 through legitimation theory, which focuses more on the processes rather than the result. Deegan cites Lindblom's (1994) explanation of the difference between legitimation and legitimacy, with legitimation being "the process that leads an organisation being adjudged legitimate”, and legitimacy as “a status or condition” (Deegan, 2006, p. 275; Deegan, 2007, p. 127). Richardson defines legitimation as the processes "which create and validate the normative order of society" (1987, p. 343); whereas Wiseman (1980, p. 90) and Dirsmith (1986, p. 358) suggest that legitimation is the process where social knowledge and expectations explain and justify social behaviour and the changes of social institutions (organisations). Berger and Luckmann (1966) suggest that the process of legitimation is a societal necessity of "keeping chaos at bay" (p. 121); while Hopwood (1987, cited in Richardson, 1987, p. 347) suggests legitimation is a:

...process of creating rationales which give order to a chaotic array of actions arising out of the pragmatic problems facing society. Organisations will use different legitimating processes depending on whether the organisation wants to build, regain or extend its legitimacy (O’Donovan, 2002, p. 349).

However, Deegan explains: 
...that an organisation seeking to be legitimate it is not the actual conduct of the organisation that is important, it is what society collectively knows or perceives about the organisation's conduct that shapes legitimacy (2007, p. 128).

Richardson (1987) suggests that three different perspectives of legitimation exist: structural functionalist, social constructionalist and hegemonic (p. 342). The structural functionalist perspective "presumes that both values and actions are defined by the functions which must be performed for a social system to survive” (Richardson, 1987, p. 343); whereas the social constructionalist perspective "regards values as emerging from interaction among members of society” (Richardson, 1987, p. 343). The hegemonic, dominance through noncoercive means, perspective "regards values as an aspect of elite ideologies" (Richardson, 1987, p. 343) and therefore should remain unquestioned (Rahaman et al., 2004, p. 40).

These three perspectives reflect different ontological assumptions - "the nature of being or reality" (Dillard, 1991, p. 11). Morgan and Smirch (1980) suggest a continuum of ontological assumptions exist, ranging from reality as a concrete structure (structural functionalist perspective) to reality a social construction (social constructionalist) to reality as a projection of human imagination (completely internal to the researcher). Burrell and Morgan's (1979) model suggests ontological assumptions can either be founded on reality which exists independently of the individual (realism - structural functionalist perspective), or reality which is created based on artificial creations for describing and making sense of the external world (nominalism - social construction) (Burrell and Morgan, 1979, p. 4). This model is also reflected in Gaffikin who uses the terms realist and constructionist (Gaffikin, 2008).

Reality as a social construction assumes that reality is a continuous process created through the medium of language, labels, actions and routines (Burrell and Morgan, 1979, p. 4; Morgan and Smircich, 1980, p. 494). This paper focuses on the social constructionalist perspective of legitimation.

Richardson (1987) explains that the:

...social constructionalist perspective regards values as emerging from interaction among members of society. These values are usually directed [determined] by certain groups in society who are seen to be experts, such as professionals [for example, accountants] (p. 343).

These "professionals" contribute to the knowledge with which society can construct its social reality (Richardson 1987, p. 348). Reality as a social construction assumes that reality (social world external to the individual) is a continuous process created through the medium of language, labels, actions and routines (Burrell and Morgan 1979, p. 4; Morgan and Smircich, 1980, p. 494). Under this assumption of reality, Morgan and Smircich (1980) suggest that "human beings create their realities in the most fundamental ways, in an attempt to make their world intelligible to themselves and to others" (p. 494). This is consistent with Boland and Pondy's (1983) discussion of groups of people (management) who, as being responsible for others, construct their social reality through symbolical interaction, and in turn "give meaning to their ongoing stream of experience” (p. 223).

The social constructionalist perspective sees the social world as an emergent social process which is created by the individuals concerned. Social reality, insofar as it is recognised to have any existence outside the consciousness of any single individual, is 
regarded as being little more than a network of assumptions and intersubjectively ${ }^{5}$ shared meanings. (Burrell and Morgan 1979, p. 29). Through the publication of their corporate social responsibility reports, financial institutions construct an image they wish to portray and be accepted by society. The use of generally accepted terms such as "environmental reporting" creates an impression that they are environmentally aware, even if the reports do not actually provide transparent information on their performance and management. For example, HSBC used the Equator Principles as such a tool in undertaking legitimation processes.

The following section of this paper examines and reviews the environmental performance and reporting developments in China, with specific reference to the reporting practices of two note-issuing banks in Hong Kong: the Hongkong and Shanghai Banking Corporation (HSBC) and Bank of China (Hong Kong) Limited (BOCHK) for the period 2003 to 2006. China has a "one country, two systems" policy, where Hong Kong maintains a capitalist economy, based on common law established by the British, while China follows the civil law system.

\section{Environmental Performance and Management Reporting in China}

The State Environmental Protection Administration (SEPA, now the Ministry of Environmental Protection, MEP) of China signed a deal with the International Finance Corporation (IFC) in Beijing on 24 January 2008 to introduce the Equator Principles in China (China Daily, 2008; International Finance Corporation, 2008; Bosshard, 2008a). The SEPA and IFC conducted joint research on adapting the Equator Principles as well as developing environmental benchmarks for lending in China's financial sector. SEPA, which is not a political heavyweight in Beijing's power apparatus, state that it believes the use of adequate market tools (integrating the Equator Principles into China) will have an impact on the industrial sector in encouraging business to recognise the environmental costs of their operations and thus focus on reducing the likelihood of environmental problems from the beginning (Bosshard, 2008b; Guo, 2008). SEPA is the only national government department sanctioning companies that do not comply with the Equator Principles. However, none of the measures adopted by SEPA explicitly refer to the environmental track record of Chinese overseas investors.

Several positive developments have occurred in China's banking sector in relation to social responsibility. In 2007 an increased number of banks ${ }^{6}$ released CSR reports that covered various aspects, including corporate governance, employee relations and philanthropic activities. Although they did not focus on how the environmental and social issues affect the banking/lending business, these reports are a starting point for Chinese banks to practise non-financial disclosures (Guo, 2008). At the end of 2006, the People's Bank of China (PBOC, China's central bank) collaborated with SEPA to integrate information on corporate pollution records into the database for corporate credit. PBOC then urged all commercial banks in China to conduct a strict screening of environmental issues in their lending process. This increased focus contributed to the Industrial Bank in China being awarded runner-up in the Financial Times 2007 Sustainability Banking Awards (Gao et al., 2005; Financial Times, 2007), which "recognise banks and other financial institutions that

\footnotetext{
${ }^{5}$ Intersubjectivity: The world is experienced not as the private world of a single individual, but as an intersubjective world common to us all. We interpret events in a manner which is identical for all practical purposes and assume that we all have broadly the same experience if we were to change places. Thus, we routinely make sense of the other's talk and action and achieve our own "acceptable" activities (Silverman, 1975, p. 277).

${ }^{6}$ For example, the China Construction Bank, Shanghai Pudong Development Bank and China Merchant Bank.
} 
have shown leadership and innovation in integrating social, environmental and corporate governance considerations into their operations" [emphasis added] (Financial Times, 2008).

\section{Hongkong and Shanghai Banking Corporation (HSBC)}

The HSBC is one of the world's largest banking groups. It was founded in Hong Kong in 1865 when the position of the western powers in China was strengthened by the Treaty of Nanking, ${ }^{7}$ which opened an immense expansion of trade with the West. HSBC became a local Hong Kong organisation financing trade for the Treaty Ports of China, and which was owned by the local mercantile community (Benton, 1983; Chiu, 1973; Tsai, 1993). The same year that the HSBC was founded it began issuing bank notes. HSBC was by far the largest bank in Hong Kong and the UK. It was ranked the world's largest banking group by Forbes in 2008 (Forbes, 2008). It was also named the world's most valuable banking brand by The Banker magazine (The Banker, 2008).

In 2003, when the Equator Principles were first released, the HSBC was one of the initial ten financial institutions to adopt the Principles. Since then, the HSBC has chaired the Equator Principles working group in 2005 and played a major role in the redrafting of the Equator Principles in 2006 (HSBC, 2006a). The HSBC won the Sustainable Bank of the Year 2006 in the first Financial Times Sustainability Banking Awards, and while HSBC may have disclosed their environmental performance and management to "win a particular reporting award” (Deegan 2002, pp. 291), other factors may have contributed to HSBC's application for (and possibly winning of) the award. These awards were launched by the Financial Times "in association with the International Finance Corporation, the private sector arm of the World Bank Group" (Financial Times, 2006a). The Equator Principles are based on the environmental reporting principles of the International Finance Corporation (Equator Principles, 2003). The commentary by the Financial Times included that one of the reasons for winning the award was for it being the "leading adopter of Equator Principles" (Financial Times, 2006b). This prompts the question about the legitimacy (real, rather than apparent) of the awards. Have these organisations, including HSBC, created and then adopted the Equator Principles and then, in conjunction with the Financial Times, created a publicly recognised environmental reporting award? The conflict of interest is apparent: HSBC played a major role in redrafting the Equator Principles and later won an award for being a "leading adopter of Equator Principles” (Financial Times, 2006b).

Between 2003 and 2006 HSBC produced annual corporate responsibility reports, which are separate from their annual report. These reports discussed, in general terms, the organisation's adoption of the Equator Principles, but except for the 2006 report, provided little detailed environmental performance or management information based on the Equator Principles (Andrew, 2007, p. 45). Even though HSBC actively promotes their environmental credentials (legitimation process), they may still be unsure if a focus on environmental performance and management is appropriate. For example, in HSBC's 2006 Corporate Responsibility Report the first page focuses on the financial highlights of the group (refer to Appendix 3), while further down the page (in much smaller font) HSBC outlines:

In 2006, HSBC played a major role... in relaunching the Equator Principles (EPs) global environment and social guidelines for project finance. These new guidelines

\footnotetext{
${ }^{7}$ Treaty of Nanking, August 1842, was a Peace Treaty between the Queen of Great Britain and the Emperor of China which ended the first opium war that started due in May 1839. (http://web.jjay.cuny.edu/ jobrien/reference/ob24.html)
} 
improve the social standards that apply to financing projects and require greater transparency of reporting on implementation (HSBC, 2006a, p. 1).

In 2005 the Head of HSBC Group Sustainable Development, Jon Williams, claimed that the Equator Principles were a cornerstone of the bank's approach to how they financed projects and contributed to sustainable development. He also claimed that HSBC provided 30 per cent more project loans and declined fewer deals due to the bank's training of their staff with the internal and external requirements for compliance of the Principles (HSBC, 2006b). However, the bank did not provide any details on how they achieved an increase of project loans, the nature of these projects or how they might help improve the society and environment.

In 2006 the HSBC engaged an international consulting firm headquartered in Oslo, Norway, Det Norske Veritas ${ }^{8}$ (DNV), to review their adherence to the Equator Principles. Jon Williams, Head of HSBC Group Sustainable Development, implied that a positive review done of HSBC was independent ('third party'), and it enhanced their environmental credibility. But, HSBC paid for it. This statement also implies that the notion of transparency, a key factor in credible reporting, cannot be truly met if confidentiality is a guiding principle of the review. Mr Williams also claimed that this review was received positively by all types of interested parties, including NGOs, other banks, lawyers and accountants. He admitted that financial institutions such as HSBC had been under increasing pressure to disclose more information about how the Equator Principles were applied. He also believed that other financial institutions would follow suit in providing more detailed corporate social responsibility reporting and provide a third-party verification (DNV, 2007, p. 16). These comments are consistent with the actions and implied objectives of China's State Environmental Protection Administration.

On their website, DNV states that:

Companies are today facing a new risk reality, as they are increasingly being held accountable for global climate change, fraud, corruption, pollution, labour abuse and more. Falling to act responsibly, the company will be punished in the public opinion, and the environment and society will suffer along with the company's brand reputation ${ }^{9}$.

DNV claims that their verified report can help manage shareholder and stakeholder expectations which verifies the organization's legitimacy, as well as signal the commitment to national, international and/or industry standards for corporate responsibility. Yet with such grand objectives, DNV expressly disclaims any liability or responsibility for any third-party decision based on the assurance statement.

DNV concluded from its work on the assurance engagement they undertook for HSBC (refer to Appendix 2) that HSBC:

...has good processes in place to ensure an adequate adoption of the Equator Principles. These are supported by a range of sector policies and associated guidelines and tools. There is a good level of awareness of the Equator Principles among

\footnotetext{
${ }^{8}$ A Norwegian company which provides, for several industry sectors such as IT, finance, climate change, food, automotive, energy, aerospace and health care services for managing risk and certification.

${ }^{9}$ http://www.dnv.com/services/assessment/corporate_responsibility/index.asp accessed 22 September 2008
} 
personnel in the Credit and Risk functions, Project Export Finance and Sustainability Risk Managers. There is evidence of commitment and good collaboration between staff in these areas with regards to the adoption of Equator Principles and sustainability in general (DNV, 2008).

HSBC adopted the Equator Principles as a legitimation tool, but they were also influenced by the global (including the Chinese state) political pressure in relation to following marketbased reporting solutions. This is reflected in the DNV's assurance statement of HSBC's adherence to the Equator Principles. However, not all financial institutions in Hong Kong have adopted the Equator Principles. The next section discusses the environmental disclosure of a non-adopting Equator Principles financial institution in Hong Kong.

\section{Bank of China Hong Kong (BOCHK)}

Bank of China opened its first branch in Hong Kong in 1917, which marked the entry of stateowned Chinese banks into the colony's banking sector. In 2001 BOCHK was established by combining the businesses of ten of the twelve banks in Hong Kong originally belonging to Bank of China Group (Bank of China (Hong Kong), 2008a). BOCHK is part of the second largest banking group in Hong Kong, in terms of assets and deposits, and began issuing bank notes in Hong Kong in 1994, three years before the transfer of the sovereignty of Hong Kong back to China from the British. While it is legally separate from its parent Bank of China (BOC), it maintains close relations in management and administration, and co-operation in various areas, including the reselling of BOC's insurance and securities services.

While the BOCHK has not adopted the Equator Principles, it does provide some information on its website about its environmental performance. The information provided is significantly different to the information provided by HSBC. BOCHK in 2008 provided the following environmental performance: supported the Green School Award; sponsored the Hong Kong Tree Planting Day 2006; donated refurbished computers and related accessories to the Home-School-Community Computer Donation Campaign; participated in the One Company-One Year-One Environmental Project; and supported the Ocean Park Conservation Foundation and Ecotourism in Long Valley (2008b).

So, why hasn't BOCHK adopted the Equator Principles? By looking at the market where the organisation operates, and the environmental information provided (as outlined above), BOCHK is more focused on its role within its immediate environment and community. BOCHK serves the local Hong Kong community and project funding is provided mainly for projects in Hong Kong and Mainland China. That is, rather than outlining grand objectives, it focuses on addressing specific local concerns. The Equator Principles would not be a valuable legitimation tool for BOCHK; instead, adoption might detract from improving its legitimacy and may place the reputation of the bank at risk. The current environmental performance and management disclosures of the BOCHK meet the needs of the organisation to remain legitimate in the society where it operates.

\section{Discussion and Conclusion}

Many private sector organisations use voluntary environmental performance and management reporting as means of promoting their social agenda, and partially to address the growing concern of the public about the impact of the organisations' operations on the environment. The finance sector has a set of globally developed principles, the Equator Principles, which a growing number of international financial institutions have adopted. This study examined the 
practices of two note-issuing banks in Hong Kong: HSBC, which adopted the Equator Principles, and BOCHK, which has not. Deegan suggests that environmental disclosure (adoption) decisions may be driven by the desire to survive (or be seen as legitimate) or by management's "view that the community has a right to know about the organisation's actions" (2007, p. 144). These suggestions are useful to reflect upon when considering HSBC's adoption and BOCHK's non-adoption of the Equator Principles. A review of the evidence outlined earlier in this paper suggests that the Equator Principles are a valuable legitimation tool for the HSBC, "the world's local bank" (HSBC, 2008) to maintain its legitimacy within the global financial market. While the BOCHK does not operate in the same market, instead concentrating on a local market, the adoption of the Equator Principles may not be in the organisation's best interests (legitimacy). This could be because the majority of BOCHK's stakeholders are community members of Hong Kong. If the organisation placed too much focus on the global environment, then the stakeholders could form the view their interests are being diluted in favour of minor stakeholder groups. This in turn would reduce the legitimacy the organisation holds to operate as a domestic financial institution.

In Hong Kong there are no mandatory requirements for environmental performance and management reporting disclosures of the operations of private sector organisations. However, many private sector organisations, such as HSBC and BOCHK, disclose some information on their environmental performance and management. Most of the information disclosed presents the organisations in a favourable light - there is no mention of any environmental failures in their reports. This level of disclosure could be interpreted as an attempt to avoid the implementation of mandatory environmental disclosure requirements. By voluntarily disclosing their environmental performance in relation to project lending, the HSBC's use of the Equator Principles is a legitimation tool used to help maintain legitimacy and therefore reduce the likelihood of the government intervening through the introduction of mandatory environmental reporting requirements. This legitimation process contributes to the construction of legitimating symbols within society, and reflects that HSBC could be seen as 'leaders' in environmental reporting — so much so that their actions (their social construction) ensures that other financial institutions try to conform to their version of "reality". Conversely, local banks such as BOCHK serve mainly the Chinese society in Hong Kong, and their concept of social responsibility is satisfied by the family and community, rather than the corporation. This local stakeholder perspective and the focus of BOCHK environmental reporting indicates a different a level of legitimacy, which in turn requires different legitimation processes.

Legitimation is an important process which organisations use to gain, maintain or improve their position in society. Depending on the type of business and the objective of the legitimation processes, organisations construct a social reality based on language, labels, actions and routine (Burrell and Morgan, 1979, p. 4; Morgan and Smircich, 1980, p. 494), which is communicated to society via the appropriate environmental reporting and management processes.

Although HSBC is not a central bank in Hong Kong, it is considered the leading international financial institution and the lender of last resort in the region. This societal expectation and pressure could explain the leading role the bank has taken in relation to the implementation and adoption of the Equator Principles. In contrast, the BOCHK does not face the same societal expectation in taking a global perspective with their financing activities. Instead, their focus is on the domestic market in Hong Kong. 
China does not have a great track record of environmental protection. However, recently, China has taken steps to improve its performance significantly, for instance, the establishment of the joint research project between the Ministry of Environmental Protection and IFC in developing environmental benchmarks for China's financial sector. Also, the recent efforts of the Chinese authorities to reduce the extreme levels of pollution in Beijing in the lead-up to the 2008 Olympic Games indicates a genuine concern for the environment. But is this behaviour a true concern for the environment, or was it done just to legitimise their position in the global community to avoid international criticisms and pressures?

The adoption of the Equator Principles by HSBC, and the non-adoption by BOCHK, could be viewed as part of their attempts to construct an image they wish their customers (current and future) to have of their organisations. The processes undertaken to project this view are part of the legitimation process they are actioning to strengthen their social contract within their communities. 
Appendix 1 The Equator Principles

Principle 1: Review and Categorisation

An Equator Principles Financial Institution (EPFI) will categorise each project based on the magnitude of its potential impacts and risks in accordance with the environmental and social screening criteria of the International Finance Corporation (IFC).

Principle 2: Social and Environmental Assessment

The borrower is to conduct a Social and Environmental Assessment process to address the relevant social and environmental impacts and risks of the proposed project.

Principle 3: Applicable Social and Environmental Standards

The Social and Environmental Assessment process should address compliance with relevant host country laws, regulations and permits that pertain to social and environmental matters.

Principle 4: Action Plan and Management System

For projects located in non-OECD countries, or in OECD countries not designated as HighIncome, the borrower is to prepare an Action Plan which addresses the relevant findings, and draws on the conclusions of the Assessment.

Principle 5: Consultation and Disclosure

For projects located in non-OECD countries or in OECD countries not designated as HighIncome, the government, borrower or third party expert has consulted with project affected communities in a structured and culturally appropriate manner.

Principle 6: Grievance Mechanism

For projects located in non-OECD countries or in OECD countries not designated as HighIncome, to ensure that consultation, disclosure and community engagement continues throughout construction and operation of the project, the borrower will, scaled to the risks and adverse impacts of the project, establish a grievance mechanism as part of the management system.

Principle 7: Independent Review

For all projects, an independent social or environmental expert not directly associated with the borrower will review the Assessment, Action Plan and consultation process documentation in order to assist EPFI's due diligence, and assess Equator Principles compliance.

Principle 8: Covenants

An important strength of the Principles is the incorporation of covenants linked to compliance.

Principle 9: Independent Monitoring and Reporting

To ensure ongoing monitoring and reporting over the life of the loan, EPFIs will, require the appointment of an independent environmental and/or social expert, or require that the borrower retain qualified and experienced external experts to verify its monitoring information which would be shared with EPFIs.

Principle 10: EPFI Reporting 
The Australasian Accounting Business \& Finance Journal, December, 2008.

Hui \& Bowrey: Corporate Social Responsibility Reporting of Two Note Issuing Banks

Vol. 2, No.4.

Each EPFI adopting the Equator Principles commits to report publicly at least annually about its Equator Principles implementation processes and experience, taking into account appropriate confidentiality considerations. 
DNV Assurance Statement Equator Principles

Det Norske Veritas (hereafter 'DNV') has been commissioned by HSBC Holdings plc, (hereafter 'HSBC') to provide independent third party assurance services regarding HSBC's implementation of the Equator Principles (EP).

Our responsibility in performing this work is to the management of HSBC only and in accordance with the agreed terms of reference. DNV expressly disclaims any liability or responsibility for any third party decisions, whether investment or otherwise, based upon this Assurance Statement.

Scope

This is the second year DNV has verified HSBC's implementation and disclosure of EP against the principles of the AA1000 Assurance Standard (AA1000AS) and in accordance with the EP of July 2006.

In accordance with HSBC's request, this assurance engagement was carried out through document review and interviews with relevant personnel across HSBC Group, from HSBC Headquarters in London. It focused not only on HSBC's implementation of the EP, but also on HSBC's active role in promoting and developing the EP framework, in collaboration with other financial intuitions.

Compared with last year, the sample of projects has increased significantly. Out of all projects approved by Group Corporate Sustainability in 2007. DNV selected 4 Category A projects (out of a total of 7 ) and 1 Category B (out of total of 57 ). The total value of the sample represents $12.5 \%$ of the total loan value reported. In addition, DNV selected 1 Category A project approved in 2006 (for purposes of verifying continuity and monitoring).

\section{Limitations}

This assurance engagement was carried out taking into consideration the specific nature, scale and context of each individual project verified. As the life of each project can span over a number of years (from approval to completion of loan payment), this verification was carried out taking into consideration the current stage of each project and the level of control that would be expected from HSBC at that stage. Moreover, it is recognised that each project is often financed by a number of parties. Therefore, this verification also took into consideration HSBC's stake and role in each project, as well as its relationship with other bidding or financing partners in the project.

$\mathrm{HSBC}$ requested that this assurance engagement be carried out from the Group Head Office in London. This enabled us to gain a good understanding of policy-making and EP's implementation at Group level. This was supplemented by telephone interviews with HSBC Sustainability Risk Managers in Latin America (Mexico) and Asia Pacific (Hong Kong)

Two of the projects verified by DNV were approved by Group Corporate Sustainability in the last quarter of 2007 which meant that available documentation was limited. As of April 2008, the common terms agreement of one of these projects was still pending, thus most of the documentation was not available. As a result, this verification focused on the nature and implementation of Group Corporate Sustainability's approval / clearance process.

In order to verify the continued implementation of EP at different stages in the life of projects, we also reviewed one Category A project approved in 2006 (which was also subject to review during our 2007 assurance engagement).

\section{Declaration of Independence}

DNV did not provide any services to HSBC during 2007 that could conflict with the independence of our assurance work. DNV was not involved in the preparation of any information contained in the Sustainability Report.

\section{DNV's Approach}

This assurance engagement was carried out as part of the verification of HSBC's Sustainability Report 2007. It accounted for approximately $1 / 3$ of all time spent on the verification of the Report and involved both face-to-face and telephone interviews as well as document review.

For this element of the work, the July $2006 \mathrm{EP}$, as described by the EP Secretariat was used as a basis. The overal assurance engagement was carried out in accordance with the guidelines contained in the DNV Protocol for Verification of Sustainability Reports, which is based both on the GRI G3 and the AA1000AS.

The assurance engagement was conducted between March and May 2008, by suitably qualified professionals, and comprised the following:

1. Interviewed a selection of HSBC representatives, including Group Corporate Sustainability representatives; directors of Credit and Risk, and Project and Export Finance (PEF); and Sustainability Risk Managers (SRMs) located in Mexico and Hong Kong

2. Selected a sample of projects that would give a fair representation of HSBC's potential impacts and activities, hence the focus on Category A projects. All projects selected were proposed or are being carried out in either non-OECD countries or an OECD country not classified as 'High Income'. The majority of the projects selected are within the Oil 


\begin{tabular}{|c|c|c|}
\hline 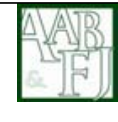 & $\begin{array}{l}\text { The Australasian Accounting Business \& Finance Journal, December, } 2008 . \\
\text { Hui \& Bowrey: Corporate Social Responsibility Reporting of Two Note Issuing Banks } \\
\text { Vol. 2, No.4. }\end{array}$ & Page 85. \\
\hline
\end{tabular}

and Gas or Power sector, which represented $45 \%$ of HSBC EP loans in 2007 . Where applicable, DNV also evaluated whether the relevant HSBC sustainability sector policy had been followed..

3. DNV had full access to all relevant project financing documentation available at HSBC Headquarters, including: technical due diligence reports by independent third parties; common terms agreement documentation; common facility agreements; internal correspondence between Group Corporate Sustainability and local PEF and SRM teams; environmental and social impact assessments; environmental action plans; and reports by independent third parties.

\section{Conclusions}

In DNV's opinion, HSBC has good processes in place to ensure an adequate adoption of the EP principles. These are supported by a range of sector policies and associated guidelines and tools. There is a good level of awareness of the EP principles among personnel in the Credit and Risk functions. Project Export Finance and Sustainability Risk Managers. There is evidence of commitment and good collaboration between staff in these areas with regards to the adoption of EP and sustainability in general.

Regarding the way in which EP related information is documented in the Sustainability Report, and taking into consideration the AA1000AS principles, the following comments are made:

- Materiality - In view of confidentiality limitations on the disclosure of project financing deals, we consider that the information contained in HSBC's Sustainability Report 2007 addresses the information requirements of its Stakeholders. We commend HSBC's decision to provide further disclosure of loans by sector in the 2007 Report. Completeness - In our opinion, the Report's section on EP provides a fair and balanced representation of HSBC's performance during 2007.

Responsiveness - We can confirm that HSBC has undertaken a comprehensive stakeholder engagement exercise in 2007. A key finding of that exercise was that Stakeholders needed further information on EP. As a result, HSBC not only increased the level of detail and transparency in the EP section of the 2007 Report, but asked DNV to expand the scope of assurance engagement to include additional projects.

\section{Commendations}

We would like to commend HSBC for the following:

- $\quad$ Documentation of EP requirements in Function Instruction Manual (FIM), accessible to all relevant employees; Commenced planned implementation of an automated internal reporting mechanism (as recommended by DNV in last year's assurance statement);

HSBC's active role in promoting the EP among other financial institutions and contribution to the development of the EP management structure and governance rules;

Local PEFs' general awareness of EP evidenced by email correspondence:

Provision of support by Group Corporate Sustainability to local offices;

Level of awareness, competence and commitment of Group Corporate Sustainability team

Use of independent experts where applicable, to challenge the Group's thinking on sustainability, guide continual improvement and provide assurance to Stakeholders;

Enhancement of monitoring requirements, e.g. Group Corporate Sustainability must be informed if projects become non-compliant with EP; should clearance be provided on a conditional basis, local group office needs to send confirmation to Group Corporate Sustainability that conditions have been in fact met.

\section{Recommendations for improvement}

- $\quad$ Rapid growth and significant staff increases in certain regions (Asia Pacific in particular) pose a challenge to ensuring that new employees are aware, competent and committed to adopting HSBC's processes and practices regarding EP and sustainability in general. Local regions, supported by Group Corporate Sustainability, should ensure that sustainability-related induction processes, training, and support are provided to new employees, as appropriate.

Continue raising awareness of approval processes within local offices, in particular regarding the need for timely approval of certain projects by Group Corporate Sustainability, as stated in the Functional Instruction Manual.

Raise awareness and deliver training to local credit teams and relationship managers on post-approval monitoring and control activities, relevant to the role of HSBC in given projects.

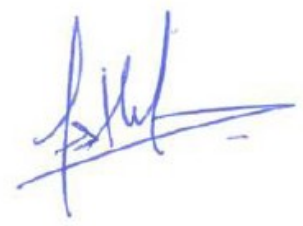

Esther Garcia Head of CR Services (UK)

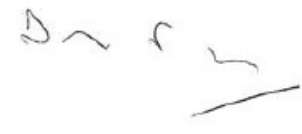

David Salmon Country Manager (UK)

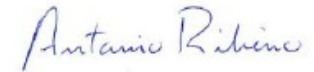

Antonio Ribeiro

Verifier

DNV Ltd

May 2008 


\section{Appendix 3}

\section{6 in Review}

Financial highlights

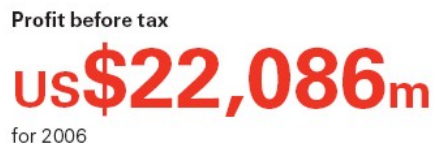

for 2006

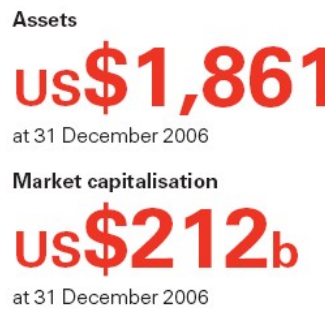

Profit before tax

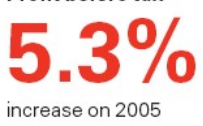

Dividends per share

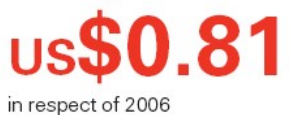

in respect of 2006

Capital strength

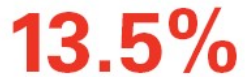

total capital ratio at 31 December 2006

\section{Achievements}

1 'Sustainable bank of the year'

HSBC was named overall winner in the first Financial Times Sustainable Banking Awards, in recognition of our leadership in merging social, environmental and business objectives.

\section{- Energy Sector Policy and Carbon} Finance Strategy

We issued our fourth sector guideline, the Energy Sector Policy, which provides guidance for our employees on the environmental and social standards recognised as good practice within the energy industry. We also launched our Carbon Finance Strategy, which advises clients on the implications of climate change, and helps them to understand the challenges and opportunities of creating a lower carbon economy.

\section{- Future First}

The HSBC Global Education Trust launched 'Future First', a five-year, US\$10 million programme to help street children, children in care and orphans around the world. The programme supports education, livelihood training and rehabilitation projects, enabling these children to enter the mainstream of society.

\section{Improving standards in the finance sector} In 2006, HSBC played a major role with the leading financial services companies and the International Finance Corporation in relaunching the Equator Principles (EPs) - global environmental and social guidelines for project finance. These new guidelines improve the social standards that apply to financing projects and require greater transparency of reporting on implementation. The EPs have been re-adopted by 52 financial institutions representing over US\$50 billion or 80 per cent of global project financing (see page 18 for more information about our implementation of the principles).

\section{Challenges}

\section{Carbon dioxide emissions}

As part of our commitment to carbon neutrality, it is important that we reduce our total carbon dioxide $\left(\mathrm{CO}_{2}\right)$ emissions over time. During 2006, our $\mathrm{CO}_{2}$ emissions per person, our key $\mathrm{CO}_{2}$ measure, increased due to a change in the type of energy we were able to purchase and an increase in air travel. We have programmes in place to reverse this trend. For a growing business, it is a challenge to reduce emissions consistently. See 'Preventing climate change' on page 24 for more information about HSBC's commitment to carbon neutrality and how we are addressing our increased $\mathrm{CO}_{2}$ emissions.

\section{Deasuring $\mathrm{CR}$ progress}

We have been reporting for some years on the environmental impacts of our operations and the diversity of our work force. However, there are other aspects of our business that may also have significant social and environmental dimensions, for which we have no global metrics. We recognise we need to develop these measures and report on them in future. 


\section{References}

ACCA (2008a) ACCA awards for sustainability reporting: http://www.accaglobal.com/publicinterest/activities/subjects/sustainability/awards/ accessed 31 July 2008.

ACCA (2008b) The ACCA Hong Kong Awards for Sustainability Reporting: http://www.accaglobal.com/hongkong/publicinterest/technical_activities/sustainability/hkera/ accessed 13 July 2008.

Adams, C.A. (2004) The ethical, social and environmental reporting-performance portrayal gap. Accounting, Auditing and Accountability Journal, 17: 731-757. https://doi.org/10.1108/09513570410567791

Andrew, J. (2007) The equator principles, project finance and the challenge of social and environmental responsibility. Issues in Social and Environmental Reporting, 1: 40-53. https://doi.org/10.22164/isea.v1i1.7

Bank of China (Hong Kong) (2008a) Corporate Profile: History: http://www.bochk.com/web/common/multi_section.xml?section=about\&level_2=bank_profile\&fldr_id =291 accessed 11 February 2008.

Bank of China (Hong Kong) (2008b) Environmental Protection: http://www.bochk.com/web/common/profile.xml?section=about\&level_2=corporate_citizenship\&fldr_i d=550 accessed 11 February 2008.

Benton, G. (1983) The Hong Kong crisis, London, Pluto Press.

Berger, P.L. and Luckmann, T. (1966) The social construction of reality: a treatise in the sociology of knowledge, New York, Doubleday.

Boland, R.J. and Pondy, L.R. (1983) Accounting in organisations: An union of natural and rational perspectives. Accounting Organisations and Society, 223-234. https://doi.org/10.1016/0361-3682(83)90030-2

Burrell, G. and Morgan, G. (1979) Sociological paradigms and organizational analysis, London, Heinemann.

Burritt, R.L. and Welsh, S. (1997) Accountability for environmental performance of the Australian Commonwealth public sector. . Accounting, Auditing and Accountability Journal, 10: 532-561

Chiu, A.C., Coppell, L. and Li, D. (2002) The State of Environmental, Social and Sustainability Reporting in Hong Kong, Hong Kong, ACCA Hong Kong.

Chiu, T.N. (1973) The Port of Hong Kong: a survey of its development, Hong Kong, Hong Kong University Press.

Coulson, A.B. (2007) Environmental and social assessment in sustainable finance, in Unerman, J., Bebbington, J. and O’Dwyer, B. (Eds) Sustainability Accounting and Accountability. London, Routledge. https://doi.org/10.4324/NOE0415384889.ch14

Deegan, C. (2002) Introduction - The legitimising effect of social and environmental disclosures - a theoretical foundation. Accounting, Auditing and Accountability Journal, 15: 288-311. https://doi.org/10.1108/09513570210435852

Deegan, C. (2006) Financial Accounting Theory, McGraw-Hill Irwin.

Deegan, C. (2007) Insights from legitimacy theory, in Unerman, J., Bebbington, J. and O’Dwyer, B. (Eds) Sustainability Accounting and Accountability. London, Routledge.

Deegan, C. and Rankin, M. (1996) Do Australian companies report environmental news objectively? Accounting, Auditing and Accountability Journal, 2, : 50 - 67 https://doi.org/10.1108/09513579610116358

Dillard, J., Rigsby, J. and Goodman, C. (2004) The making and remaking of organizational context: Duality and the institutionalization process. Accounting, Auditing and Accountability Journal, 17: 506-542. https://doi.org/10.1108/09513570410554542

Dillard, J.F. (1991) Accounting as a Critical Social Science. Accounting, Auditing and Accountability Journal, 4, : 8-28. https://doi.org/10.1108/09513579110143849

DNV (2007) DNV Forum:02 2007 http://dnv.com/resources/publications/dnv_forum/2007/no_2 accessed 6 December 2008

DNV (2008) DNV Assurance Statement Equator Principles.

Equator Principles (2003) Leading Banks Announce Adoption of Equator Principles: www.equatorprinciples.com/pr030604.html

Forbes 2008, The Global 2000: http://www.forbes.com/lists/2008/18/biz_2000global08_The-Global2000_Rank.html accessed 22 September 2008.

Financial Times (2006a) Sustainable Banking: http://www.ft.com/reports/susbanking2006 accessed 16 July 2008.

Financial Times (2006b) Sustainable Banking 2006: http://www.ft.com/cms/1/1725880e-f79f-11da-94810000779e2340,dwp_uuid=0127f756-f7bf-11da-9481-0000779e2340.html accessed 16 July 2008.

Financial Times (2007) 2007 FT Sustainable Banking Awards: http://www.ftconferences.com/sustainablebnaking07/winners.asp accessed 16 July 2008.

Financial Times (2008) 2008 Sustainable Banking Awards: http://www.ftconferences.com/sustainablebnaking/Home08.asp. 
The Australasian Accounting Business \& Finance Journal, December, 2008.

Hui \& Bowrey: Corporate Social Responsibility Reporting of Two Note Issuing Banks

Vol. 2, No.4 .

Gaffikin, M.J.R., 2008 Accounting Theory: research, regulation and accounting practice, Frenchs Forest, NSW, Pearson Education

Gao, S.S., Heravi, S. and Xiao, J.Z. (2005) Determinants of corporate social and environmental reporting in Hong Kong: a research note. Accounting Forum, 29: 233-242.

https://doi.org/10.1016/j.accfor.2005.01.002

Gray, R. and Bebbington, J. (2001) Accounting for the environment. London: Paul Chapman/Association of Chartered Certified Accountants, London.

Guthrie, J. and Parker, L.D. (1989) Corporate social reporting: a rebuttal of legitimacy theory. Accounting and Business research, 9: 343-352. https://doi.org/10.1080/00014788.1989.9728863

Ho, S., Ng, P. and Ng, A. (1994) A study of environmental reporting in Hong Kong. Hong Kong Accountant, 5: $62-65$.

Hopwood, A.G. (1987) The Archaeology of Accounting systems. Accounting, organizations and society, 12: 207-234. https://doi.org/10.1016/0361-3682(87)90038-9

HSBC (2006a) Corporate Responsibility Report HSBC Holdings PLC: http://www.hsbc.com/1/PA_1_1S5/content/assets/csr/2006_hsbc_cr_report.pdf accessed 11 February 2008.

HSBC (2006b) Financial institutions announce revision of Equator Principles 6 July 2006: http://www.hsbc.com/1/2/newsroom/news/news-archive-2006/financial-institutions-announce-revision- ofequator-principles accessed 10 January 2008.

Lindblom, C.K. (1994) The implications of organisational legitimacy for corporate social performance and disclosure. Critical Perspectives on Accounting Conference. New York.

Lohmann, L. (2008) Toward a different debate in environmental accounting: The cases of carbon and costbenefit, Accounting, Organizations and Society (in press)

Lynn, M. (1992) A note on corporate social disclosure in Hong Kong. British Accounting Review, 24: 105-110. https://doi.org/10.1016/S0890-8389(05)80001-0

Missbach, A. (2004) The Equator Principles: Drawing the line for socially responsible banks? An interim review from an NGO perspective. Palgrave Macmillan Journals, 47: 78-84. https://doi.org/10.1057/palgrave.development.1100069

Morgan, G. and Smirch, L. (1980) The Case for Qualitative Research. The Academy of Management Review, 5: 491-500. https://doi.org/10.5465/amr.1980.4288947

Ng, A.Y. (2000) Go green: More cause than concern. Australian CPA.

O’Donovan, G. (2002) Environmental disclosures in the annual report: Extending the applicability and predictive power of legitimacy theory. Accounting, Auditing and Accountability Journal, 15: 344-371. https://doi.org/10.1108/09513570210435870

Rahaman, A.S., Lawrence, S. and Roper, J. (2004) social and environmental reporting at the VRA: institutionalised legitimacy of legitimation crisis? Critical Perspectives on Accounting, 15: 35-56. https://doi.org/10.1016/S1045-2354(03)00005-4

Richardson, A.J. (1987) Accounting as a legitimating institution. Accounting, Organizations and Society, 12: 341-355. https://doi.org/10.1016/0361-3682(87)90023-7

The Banker 2008, Hot Brands: http://www.thebanker.com/news/fullstory.php/aid/5640/HOT_BRANDS.html accessed 22 September 2008.

The Hong Kong Institute of Chartered Secretaries (2006) Environmental Reporting - Breaking the silence on environmental risk, The Hong Kong Institute of Chartered Secretaries, 1-74.

Tsai, J.F. (1993) Hong Kong in Chinese history: community and social unrest in the British Colony, 1842-1913, New York, Columbia University Press. https://doi.org/10.7312/tsai91458

Wilmshurst, T.D. and Frost, G.R. (1999) Corporate environmental reporting: A test of legitimacy theory. Accounting, Auditing and Accountability Journal, 13: 10-26.

Wiseman, J.D. (1980) The Sociology of Knowledge as a Tool of Research Into the History of Economic Through. American Journal of Economics and Sociology, 39: 83-94. https://doi.org/10.1111/j.1536-7150.1980.tb01263.x

World Bank Group (2008): http://web.worldbank.org/WBSITE/EXTERNAL/EXTABOUTUS/EXTARCHIVES/0,,contentMDK:20 035653\%7EmenuPK:56305\%7EpagePK:36726\%7EpiPK:36092\%7EtheSitePK:29506,00.html accessed 22 September 2008.

Wright, C. and Rwabizambuga, A. (2006) Institutional pressures, corporate reputation, and voluntary codes of conduct: An examination of the equator principles. Business and Society Review, 111: 89-117. https://doi.org/10.1111/j.1467-8594.2006.00263.x 